\title{
The Application of Mucoadhesive Chitosan Nanoparticles in Nasal Drug Delivery
}

\author{
Soojin Shim ${ }^{1,+}+\mathbb{D}$ and Han Sang Yoo ${ }^{1,2, *(\mathbb{C})}$ \\ 1 Department of Infectious Diseases, College of Veterinary Medicine, Seoul National University, \\ Seoul 08826, Korea; shimsj@iis.u-tokyo.ac.jp \\ 2 BioMax/N-Bio Institute, Seoul National University, Seoul 08826, Korea \\ * Correspondence: yoohs@snu.ac.kr; Tel.: +82-2-880-1263 \\ + Present address: Department of Mechanical and Biofunctional Systems, Institute of Industrial Science, \\ University of Tokyo, Tokyo 153-8505, Japan.
}

Received: 2 November 2020; Accepted: 26 November 2020; Published: 29 November 2020

check for updates

\begin{abstract}
Mucosal delivery of antigens can induce both humoral and cellular immune responses. Particularly, the nasal cavity is a strongly inductive site for mucosal immunity among several administration routes, as it is generally the first point of contact for inhaled antigens. However, the delivery of antigens to the nasal cavity has some disadvantages such as rapid clearance and disposition of inhaled materials. For these reasons, remarkable efforts have been made to develop antigen delivery systems which suit the nasal route. The use of nanoparticles as delivery vehicles enables protection of the antigen from degradation and sustains the release of the loaded antigen, eventually resulting in improved vaccine and/or drug efficacy. Chitosan, which exhibits low toxicity, biodegradability, good cost performance, and strong mucoadhesive properties, is a useful material for nanoparticles. The present review provides an overview of the mucosal immune response induced by nanoparticles, recent advances in the use of nanoparticles, and nasal delivery systems with chitosan nanoparticles.
\end{abstract}

Keywords: chitosan nanoparticles; nasal vaccines; mucosal delivery system

\section{Introduction}

Mucosal membranes line internal tissues of the body including respiratory, gastric, and genital tracts. The mucosal system has a broad recognition system which is called the "common mucosal immune system"; the stimulation of a local mucosal immune response could induce systemic mucosal immune response [1]. Therefore, using this common mucosal immune system, inducing an antigen-specific immune response throughout the body could be strategically advantageous for developing mucosal vaccines. In the upper respiratory tract, the nasal-associated lymphoid tissue (NALT) has an important role in induction of the mucosal immune responses [2]. It contains microfold cells ( $\mathrm{M}$ cells) that phagocyte and transport antigens across the mucosal membrane [3]. NALT also contains immunocompetent cells such as $\mathrm{T}$ cells and $\mathrm{B}$ cells that are mainly involved in antigen recognition and antigen presentation [4]. Nasal vaccination offers various advantages compared to the parenteral strategy, such as the need for only a small dose of antigen, increased patient compliance, and stimulation of systemic mucosal immune responses.

However, the induction of the mucosal immune response remains a challenge because antigens need to overcome rapid clearance in the mucosal membrane and reach the inductive site of the mucosal immune system. In the field of drug delivery, the research on developing nanoparticles using biopolymers to overcome the mucosal barrier and optimize the effective concentration of antigens in the body is highly prolific [5]. Chitosan is a polysaccharide polymer produced by alkaline 
deacetylation of chitin [6]. It has a positive charge that may interact with negatively charged mucosal surfaces [7]. In addition to the mucoadhesive property, the use of chitosan nanoparticles (CNs) in nasal delivery could be a good option as they have some advantages for a mucosal delivery system including biocompatibility, sustained release of loaded drug and/or antigen, a wide range of applicable conditions, high stability, and low toxicity [8]. This review provides an overview of the induction of mucosal immune response by nanoparticles, recent advances in nanoparticles, and a mucosal delivery system via the nasal cavity using CNs.

\section{Mucosal Delivery System}

Most infections by pathogens occur at or through mucosal surfaces. For an ideal vaccine, there are some expected attributes that can prevent the pathogen from initial attachment, colonization of the mucosal epithelium, and replication in the mucosa [5]. Mucosal immunization with appropriate antigens can induce both humoral and cellular immune responses throughout the body $[1,9]$. To develop a mucosal vaccine targeting particular systems, an antigen delivery system must be be considered.

\subsection{Induction of Mucosal Immunity}

Organized inductive sites of mucosal immunity are in areas where pathogens and commensal bacteria are most likely to enter the body [1]. The aggregations of mucosal lymphoid follicles are called mucosa-associated lymphoid tissue (MALT), which comprises the mucosal immune system that can function independently of the systemic immune system [10]. In addition to NALT, MALT is composed of bronchial-related lymphatic tissue (BALT) and intestinal-related lymphatic tissue (GALT) [1]. The follicle-associated epithelium contains $\mathrm{M}$ cells that induce transcytosis of antigens across the epithelium to underlying mucosal cells such as B cells and dendritic cells (DCs) [11].

MALT contains DCs, macrophages, T cells, and B cells [11,12]. These are immunocompetent cells that are responsible for generating the antigen-specific immune response. An antigen is transported to the NALT or Peyer's patches via M cells $[5,13]$. Antigen-presenting cells (APCs) process and present antigens to $\mathrm{T}$ cells in these lymphoid tissues. Chemokine-chemokine receptor interactions, such as those between chemokine ligand (CCL) 20 and chemokine receptor (CCR) 6, are involved in the antigen presentation of APCs to T cells [14]. Then, naïve $\mathrm{T}$ cells generate antigen-specific $\mathrm{T}$ cell subsets, including Th1, Th2, Th17, and cytotoxic T cells $[10,15]$. CD4+ T cells that are stimulated by DCs also induce IgA-committed B cell development including IgA class switching and affinity maturation in the germinal center [16]. Then, B cells migrate from the NALT and Peyer's patches to the cervical and mesenteric lymph nodes, respectively [13]. Activation of cytokines, including transforming growth factor (TGF)- $\beta$, IL-2, IL-4, IL-5, IL-6, and IL-10, is involved in differentiation of IgA-producing B cells into plasma cells $[13,17]$. IgA-producing plasma cells subsequently produce dimeric or polymeric forms of IgA. Dimeric IgA becomes secretory IgA by binding to polymeric Ig receptors (pIgR) on the epithelial cells of the mucosal membranes and are released into the mucosal tract $[3,18,19]$.

\subsection{Mucosal Administration Route}

The traditional mucosal administration routes are oral and nasal routes, and the immune induction sites differ according to immunization route $[5,20]$. Oral immunization is effective in inducing the immune response in the gastrointestinal tract, salivary glands, and mammary glands, while intranasal immunization is effective in the respiratory, gastric, and genital tracts [21,22]. These broad recognition systems are called the "common mucosal immune system" [18,19]. The production of IgA upregulates the expression of adhesion molecules for specific tissues and chemokine receptors that can induce homing of lymphocytes back to mucosa throughout the body $[16,19]$. For example, CCL28, the ligand for CCR10, is expressed in epithelial cells from several tissues, including the intestines, salivary glands, tonsils, upper and lower respiratory tract, and mammary glands [23]. Activated IgA-secreting B cells in mucosa express CCR10 so that CCR10 + IgA + B cells are attracted to these molecular expressing epithelial cells and induce systemic specific IgA responses throughout the body [19,24]. Secreted 
mucosal IgA intercepts, excretes and neutralizes antigens [25]. In addition, the production of serum IgA and IgG can also be induced by local immunization. The B cells activated in mucosa express peripheral homing receptors such as $\alpha 4 \beta 1$-integrin and leukocyte (L)-selectin, and these B cells can be spread throughout the body, producing antigen-specific immunoglobulin [19]. These mechanisms are advantageous for vaccination strategies for mucosal immunity as well as host defense since the appropriate activation of local mucosal immunity can induce systemic immune responses. As a well-known mucosal vaccine, an oral vaccine for poliovirus has been shown to induce mucosal IgA and systemic IgG production, and its efficacy is over 90\% worldwide [21]. Other mucosal immunization routes are the rectal, vaginal, pulmonary, conjunctival, sublingual, and transcutaneous routes. The advantages, disadvantages, and the inductive sites of mucosal immunity according to these routes are summarized in Table 1.

Table 1. Mucosal effector sites associated with immunization routes.

\begin{tabular}{|c|c|c|c|c|}
\hline Route & Advantages & Disadvantages & $\begin{array}{l}\text { Inductive Site for Iga } \\
\text { Antibody Responses }\end{array}$ & Ref. \\
\hline Nasal & $\begin{array}{l}\text { Primary invasive site for } \\
\text { airborne pathogens } \\
\text { Easy access to mucosal immune } \\
\text { induction sites permits less } \\
\text { antigen compared with oral } \\
\text { administration }\end{array}$ & $\begin{array}{l}\text { Degradation of antigen by host } \\
\text { Adjuvants are required }\end{array}$ & $\begin{array}{ll}\text { - } & \text { Upper } \\
& \text { respiratory tract } \\
\text { - } & \text { Lower } \\
& \text { respiratory tract } \\
\text { - } & \text { Reproductive tract } \\
\text { - } & \text { Blood }\end{array}$ & {$[2,26,27]$} \\
\hline Oral & $\begin{array}{l}\text { Induction of mucosal immune } \\
\text { responses to other sites through } \\
\text { the mucosal immune network } \\
\text { Primary invasive site for } \\
\text { airborne pathogens }\end{array}$ & $\begin{array}{c}\text { Degradation of antigen by gut } \\
\text { digestive process and bacterial } \\
\text { proteases } \\
\text { High doses required }\end{array}$ & $\begin{array}{ll}\text { - } & \text { Stomach } \\
\text { - } & \text { Small intestine } \\
\text { - } & \text { Colon } \\
\text { - } & \text { Blood }\end{array}$ & {$[26,28]$} \\
\hline Vaginal & $\begin{array}{l}\text { May be advantageous for } \\
\text { sexually transmitted diseases }\end{array}$ & $\begin{array}{l}\text { Poor patient compliance } \\
\text { Poor induction of both systemic } \\
\text { and vaginal mucosal } \\
\text { immune responses } \\
\text { Strong adjuvants are required }\end{array}$ & $\begin{array}{l}\text { - } \quad \text { Reproductive tract } \\
\text { - } \quad \text { Blood }\end{array}$ & {$[1,29]$} \\
\hline Rectal & $\begin{array}{l}\text { May be advantageous for } \\
\text { sexually transmitted diseases }\end{array}$ & $\begin{array}{l}\text { Poor patient compliance for } \\
\text { immunization } \\
\text { Strong adjuvants are required }\end{array}$ & $\begin{array}{ll}\text { - } & \text { Colon } \\
\text { - } & \text { Rectum } \\
\text { - } & \text { Blood }\end{array}$ & {$[1,9]$} \\
\hline
\end{tabular}

Among the immunization routes, the nasal route has been preferred, since the nasal mucosa is a layer consisting of specialized antigen-sampling M cells overlaying the NALT [4]. The well-organized lymphoid tissue contains immunocompetent cells, including DCs, T cells, and B cells, that play key roles in the induction of an immune response in the URT [17]. Th0 cells are shown to be involved in NALT from naïve mice [2]. Therefore, after M cell uptake of the inhaled antigen, the immunocompetent population within NALT can induce $\mathrm{T}$ helper cell subsets corresponding to the antigen. In addition to the existence of NALT, the nasal route is considered an attractive route for administration, with the following advantages. Intranasal immunization requires fewer antigen doses than the parenteral and oral routes because the nasal cavity shows relatively less enzymatic degradation of antigens [30]. Another study showed that intranasal immunization induces less rapid but longer-lasting mucosal and serum antibody kinetics than oral immunization in humans [31]. The uptake of antigen into the blood circulatory system after intranasal immunization is shown to be relatively fast [32]. Intranasal immunization also led to an increase in antigen-specific lymphocyte proliferation, cytokine production, and induction of specific IgA antibodies [33-35]. Despite these advantages of nasal vaccines, there are several limitations, such as rapid mucociliary clearance and the enzymatic barrier, which interferes with the uptake of vaccines. Therefore, the delivery system of an antigen must be considered, since successful development of nasal vaccines depends largely on the vaccine delivery to the nasal mucosal surface [36]. 


\subsection{Nanoparticles in Vaccine Delivery}

Drug delivery is a method or process in which a pharmaceutical compound is administered for a higher therapeutic effect [26]. To improve the safety and efficacy of drugs or antigens, several drug delivery systems have been formulated using natural product-based carriers, including liposomes, micelles, and polymeric nanoparticles [27,37,38]. The internalization mechanisms of nanoparticles are different according to particle size, surface charge, loaded antigen, and types of cells [39-41]. A wide variety of polymers, including poly (D,L-lactide-coglycolide) (PLGA), poloxamers, chitosan, alginate, liposomes, and hydrogels, have been used for drug delivery in the mucosal surface [42]. The higher intestinal transport of smaller $(\sim 300 \mathrm{~nm})$ particles than larger particles via enterocytes and $\mathrm{M}$ cells has been observed in vivo [43]. The size of $<1 \mu \mathrm{M}$ is reported as the preferred particle size for uptake by $\mathrm{M}$ cells [42]. The size of particles impacts cellular uptake and accumulation rates in the tissue due to its influence on the adhesion strength between nanoparticles and cellular receptors [44]. As for $\mathrm{M}$ cells, the transport of nanoparticles is considered to be mediated by many mechanisms of endocytosis. Several studies suggest that caveolin-1 [45] and clathrin [46] play a crucial role in the entry of nanoparticles into M cells. Another study suggests that nanoparticle endocytosis of $\mathrm{M}$ cells is most likely micropinocytosis [47]. For some nanoparticles, Toll-like receptor (TLR)-mediated stimulation has been also shown in several studies [39,48-50]. The previous literature in this field remains controversial but some suggest that the large size of nanoparticles may directly associate with TLRs [50]. On the other side, others suggest that the nanoparticle may act as a binding protein molecule due to its size and then the complex activates further TLR signaling pathways [51]. M cells have been shown to have the ability to discriminate between different commensal bacteria and modify subsequent immune responses [52]. Physicochemical properties of nanoparticles, including size, shape, surface potential, and hydrophobic/hydrophilic balance, may exert their effects on the mechanism selection of nanoparticle uptake of M cells (Figure 1).

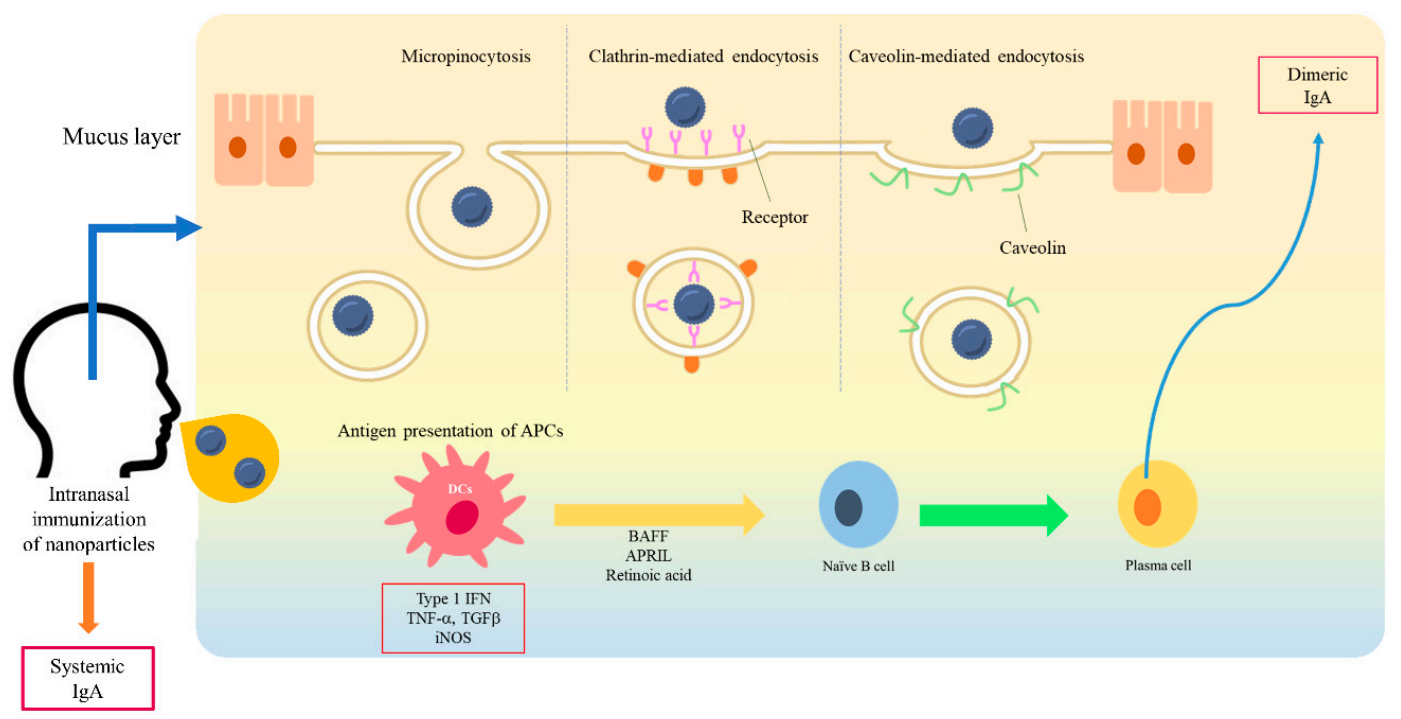

Figure 1. A schematic diagram of interaction between nanoparticles and a mucosal membrane, and the induction of mucosal immunity. At the mucosal membrane, the transport of nanoparticles is considered as mediated by caveolin-1, clathrin, and micropinocytosis into M cells. After antigen presentation, B cells migrate from the NALT to the cervical lymph nodes. IgA-producing plasma cells subsequently produce dimeric or polymeric forms of IgA. Dimeric IgA becomes secretory IgA on the epithelial cells of the mucosal membranes and is released into the mucosal tract.

The design of nanoparticle size is crucial to provide the best effects on cellular uptake and pharmacokinetics. Additionally, surface modification of nanoparticles alters ligand specificity and availability to interact with APCs [53]. Positively charged particles also exhibit enhanced mucoadhesive 
properties over negatively charged particles [54]. Conjugation of CD47 on the surface of nanoparticles minimized cellular uptake and enhanced their functionality to expand antigen-specific T cells [55]. Nanoparticles have the potential for many biomedical applications according to their specific properties. The nanoparticles used in mucosal delivery are summarized in Table 2.

Table 2. Nanoparticles used in drug delivery systems.

\begin{tabular}{|c|c|c|c|c|c|}
\hline $\begin{array}{l}\text { Polymeric } \\
\text { Materials }\end{array}$ & Size (nm) & Route & Antigen & Descriptions & Ref \\
\hline Chitosan & 200 & Intramuscular & $\begin{array}{l}\text { ptfA gene of } \\
\text { Pasteurella } \\
\text { multocida }\end{array}$ & $\begin{array}{l}\text { Elicited significant IgG response } \\
\text { in chicken. Conferred partial } \\
\text { protective immunity against } P . \\
\text { multocida challenge. }\end{array}$ & {$[56]$} \\
\hline Chitosan & 254 & $\begin{array}{l}\text { Intra- } \\
\text { muscularperitoneal }\end{array}$ & $\begin{array}{l}\text { Bacillus } \\
\text { anthracis toxin, } \\
\text { protective } \\
\text { antigen (PA) }\end{array}$ & $\begin{array}{l}\text { Elicited significant IgG (IgG2a } \\
\text { dominantly) response in mice. } \\
\text { Conferred } \sim 83 \% \text { protective rate } \\
\text { against } B . \text { anthracis challenge. }\end{array}$ & {$[57]$} \\
\hline Chitosan & $\begin{array}{l}228 \\
-399\end{array}$ & Oculo-nasal & $\begin{array}{l}\text { Inactivated } \\
\text { bronchitis virus }\end{array}$ & $\begin{array}{l}\text { Elicited significant specific } \operatorname{IgA} \\
\text { and } \operatorname{IgG} \text { response in mice. }\end{array}$ & [58] \\
\hline Chitosan & $\begin{array}{l}300 \\
-350\end{array}$ & Nasal & $\begin{array}{l}\text { Influenza } \\
\text { hemagglutinin }\end{array}$ & $\begin{array}{l}\text { Elicited the significant } \\
\text { IFN- } \gamma \text {-secreting cells in spleens of } \\
\text { mice. Conferred } 100 \% \text { protective } \\
\text { rate against influenza virus } \\
\text { challenge. }\end{array}$ & [59] \\
\hline Chitosan & 116.6 & Oral & $\begin{array}{l}\text { E. coli O157:H7 } \\
\text { recombinant } \\
\text { EIT and STX } \\
\text { toxin }\end{array}$ & $\begin{array}{l}\text { Elicited significant specific IgA } \\
\text { and IgG response in mice. } \\
\text { Conferred partial protective } \\
\text { immunity against } E \text {. coli } \mathrm{O} 157: \mathrm{H} 7 \\
\text { challenge }\end{array}$ & {$[60]$} \\
\hline PLGA & 300 & Subcutaneously & $\begin{array}{l}\text { Leishmania } \\
\text { antigens }\end{array}$ & $\begin{array}{l}\text { Elicited significant IgG (IgG2a } \\
\text { dominantly) response in mice. } \\
\text { Conferred high protective rate } \\
\text { against } L \text {. infantum challenge. }\end{array}$ & {$[61]$} \\
\hline PLGA & 633 & Intraperitoneal & $\begin{array}{l}\text { Bacillus } \\
\text { anthracis toxin, } \\
\text { PA }\end{array}$ & $\begin{array}{l}\text { Elicited significant IgG response } \\
\text { in mice. Conferred partial } \\
\text { protective immunity against } B . \\
\text { anthracis challenge. }\end{array}$ & {$[62]$} \\
\hline Dendrimer & 500 & Intramuscular & $\begin{array}{l}\text { mRNA } \\
\text { replicons }\end{array}$ & $\begin{array}{l}\text { Conferred partial protective } \\
\text { immunity against influenza virus } \\
\text { challenge in mice. }\end{array}$ & [63] \\
\hline Liposomes & $\begin{array}{l}60 \\
-120\end{array}$ & Intranasal & $\begin{array}{l}\text { Respiratory } \\
\text { syncytial virus } \\
\text { glycoproteins }\end{array}$ & $\begin{array}{l}\text { Elicited higher levels of } \\
\text { interferon- } \gamma \text { and long-term } \\
\text { memory in mice. }\end{array}$ & [64] \\
\hline Liposomes & $<200$ & Oral & $\begin{array}{l}\text { lipid-core } \\
\text { peptide }\end{array}$ & $\begin{array}{l}\text { Elicited specific } \operatorname{IgA} \text { and } \operatorname{IgG} \\
\text { response in mice. }\end{array}$ & [65] \\
\hline Liposomes & 220 & Intranasal & $\begin{array}{l}\text { Streptococcus } \\
\text { Equi antigens }\end{array}$ & $\begin{array}{l}\text { Elicited significant IgA and IgG } \\
\text { response in mice. }\end{array}$ & [66] \\
\hline Liposomes & $<200$ & Intranasal & $\begin{array}{l}\text { Highly } \\
\text { conserved B } \\
\text { and T cell } \\
\text { epitope } \\
\text { peptides }\end{array}$ & $\begin{array}{l}\text { Elicited significant IgA response } \\
\text { in pig. Conferred partial } \\
\text { protective immunity against } \\
\text { swine influenza A virus challenge. }\end{array}$ & {$[67]$} \\
\hline Liposomes & $\begin{array}{l}50 \\
/ 100 \\
/ 1000\end{array}$ & Intranasal & $\begin{array}{l}\text { Ovalbumin } \\
\text { (OVA) }\end{array}$ & $\begin{array}{l}\text { Elicited specific IgA and IgG (IgG1 } \\
\text { dominantly) response in mice. }\end{array}$ & [68] \\
\hline Silica & 150 & Intramuscular & $\begin{array}{l}\text { Avian Leukosis } \\
\text { Virus gp } 85 \\
\text { protein }\end{array}$ & $\begin{array}{l}\text { Elicited significant IgG response } \\
\text { in chicken. Conferred higher } \\
\text { protective immunity against avian } \\
\text { leukosis virus challenge. }\end{array}$ & [69] \\
\hline
\end{tabular}


Table 2. Cont.

\begin{tabular}{llllll}
\hline $\begin{array}{l}\text { Polymeric } \\
\text { Materials }\end{array}$ & Size (nm) & Route & Antigen & Descriptions & Ref \\
\hline Silica & $<1000$ & Intratracheal & $\begin{array}{l}\text { H1N1 influenza } \\
\text { hemagglutinin } \\
\text { antigen }\end{array}$ & $\begin{array}{l}\text { Elicited specific IgA and IgG } \\
\text { response in mice. }\end{array}$ & [70] \\
\hline $\begin{array}{l}\text { Inorganic } \\
\text { nanoparticles } \\
\text { (Gold) }\end{array}$ & 12 & Intranasal & $\begin{array}{l}\text { Ion channel } \\
\text { membrane } \\
\text { matrix } \\
\text { protein 2 }\end{array}$ & $\begin{array}{l}\text { Elicited specific IgG response in } \\
\text { mice. Conferred 100\% protective } \\
\text { rate against influenza virus } \\
\text { challenge. }\end{array}$ & [71] \\
\hline $\begin{array}{l}\text { Inorganic } \\
\text { nanoparticles } \\
\text { (Gold) }\end{array}$ & $<50$ & Subcutaneously & $\begin{array}{l}\text { EHEC-specific } \\
\text { immunogenic } \\
\text { antigens }\end{array}$ & $\begin{array}{l}\text { Elicited specific IgA and IgG } \\
\text { response in mice. }\end{array}$ & [72] \\
\hline
\end{tabular}

\section{Chitosan Nanoparticles in Drug Delivery}

Chitosan, the partially deacetylated form of chitin, is one of the most widely used materials for biomedical delivery vehicles [54]. CNs have been widely used in the non-parenteral drug delivery of antibiotics, proteins, and peptide drugs, and vaccines for the treatment of cancer, pulmonary or gastrointestinal diseases, and brain and ocular infections [73]. Nanoparticles prepared with chitosan possess a mucoadhesive property with a positive charge and release the drug in a sustained manner [74,75]. Moreover, they can easily control the release rate of antigens by modification of the synthesis process. Previous studies have shown that $\mathrm{CNs}$ are effective delivery systems for mucosal vaccines, especially nasal vaccines, since they enhance mucosal absorption and have adjuvant activity in the mucosal membrane $[26,54,76]$. CNs are suitable for delivery vehicles since chitosan is well known to exhibit biocompatibility [77], non-toxicity [78], antimicrobial activity [79], gel and film forming abilities [80], immune-stimulatory functions [81], and hemocompatibility [82], as well as mucoadhesiveness [83].

\subsection{Formulation of Chitosan Nanoparticles for Drug Delivery}

CNs for vaccine delivery can be formulated by several different methods including ionic gelation, microemulsion, emulsification solvent diffusion, and polyelectrolytic interaction [84]. The most common method for preparing the antigen-loaded $\mathrm{CNs}$ is the ionic gelation method that induces spontaneous self-assembly of oppositely charged materials between cationic chitosan and anionic crosslinking substrates such as tripolyphosphate (TPP) or sodium sulfate [8]. This method is preferred because the chemical nature of the components remains unaltered and it shows less toxicity than chemical crosslinking [85]. The average diameter of the $\mathrm{CNs}$ is reported to be strongly dependent on the initial chitosan concentration, the degree of deacetylation (DDA) of the chitosan, and the presence or absence of salts in the medium [86]. The DDA of chitosan is usually between $70-95 \%$ and the molecular weight ranges from 10-1000 kDa [87]. To design suitable CNs for mucosal delivery, the properties of biodegradability, mucoadhesiveness, internalization rate, $\mathrm{pH}$ sensitiveness, release rate of loaded antigen, and adjuvant activity need to be considered.

Chitosan has been found to be biocompatible since it can be metabolized by human enzymes including lysozyme [77]. Furthermore, its amino and hydroxyl groups make chemical modification easy. The interaction between chitosan and mucosal membranes is shown to be electrostatic and it can be adjusted by modifying the DDA and molecular weight of chitosan [88]. The higher molecular weight of chitosan induces stronger adhesion [89]. The charge density of chitosan-based particles depends on the DDA and also affects the mucoadhesiveness [83]. In intestines, adhesion of chitosan microspheres was stronger when the density of cross-linking of chitosan was low since the number of free amino groups in chitosan was increased [90]. In addition, the interaction between chitosan and mucosal membrane was increased at acidic pH levels [90]. 
The particle size of CNs could be adjusted by concentration or molecular weight of chitosan. Increasing chitosan concentration or molecular weight generates intermolecular hydrogen bond $(-\mathrm{OH})$ and intermolecular electrostatic repulsion with $-\mathrm{NH} 3+$ on the chitosan surface in a balanced manner and increases the size of CNs, whereas it decreases with the increase of DDA [75,83,91]. Generally, nanoparticles between 30-60 $\mathrm{nm}$ can bind to cellular receptors and drive the membrane-wrapping process without a receptor shortage affecting endocytosis [92]. On the other hand, larger nanoparticles can be loaded with larger antigens and accumulate in the liver and spleen more rapidly [93].

DDA also influences the immunotoxicity of produced CNs. In a study which compared immunotoxicity with different DDA of CNs, lower DDA CNs (80\%) were more cytotoxic for human peripheral blood monocytes and increased reactive oxygen species (ROS) production in the murine macrophage cell line, RAW 264.7 cells, compared to higher DDA CNs (93\%) [94].

Despite many applicable possibilities, chitosan exhibits a pH sensitive property; it easily dissolves at lower $\mathrm{pH}$ while it is insoluble at higher $\mathrm{pH}$. The $\mathrm{pH}$ sensitivity of chitosan could limit its application in antigen delivery as many proteins are not stable at low $\mathrm{pH}$. Therefore, modification of chitosan, including making the particles, coating with antigens, and adding derivatives, is necessary to apply chitosan as a delivery agent.

\subsection{Adjuvant Activity of Chitosan Nanoparticles}

Early studies showed that the $\mathrm{CNs}$ formed by mixing two polyelectrolytes carrying complementary charges at alkaline $\mathrm{pH}$ are biologically compatible with the mucosal surface, thereby being applicable carriers for nasal administration $[37,95]$. Positively charged CNs not only have mucoadhesive properties but also promote the internalization rate and cellular uptake compared to negatively and neutrally charged CNs [96]. CNs are shown to decrease the clearance of components from the nasal cavity, which eventually may lead to crossing the epithelial barrier and uptake by M cells [97]. CNs have also been reported to have immune-enhancing effects as adjuvants by activating macrophages and polymorphonuclear cells and inducing cytokines $[6,7,98]$. Nevagi and coworkers showed that the stimulation of protein-conjugated CNs induced DC differentiation and macrophage activation in an in vitro study [99]. Coating chitosan led to a higher interaction with Caco-2 cells compared to coating with polyethylene glycol (PEG), showing that chitosan exhibits good compliance with mucosal epithelial cells, whereas it showed a limited uptake in THP1 cells [100]. In the comparison of ion absorption by chitin nanofibers (CNFs) and CNs, absorption efficiency for CNs was greater than CNF [101]. In a comparison of drug delivery in breast cancer cell line, MCF-7 cells, between chitosan-polymerized graphene oxide and polyvinylpyrrolidone-polymerized graphene oxide nanoparticles, a chitosan nanocarrier was more suitable for application since it increased drug loading capacity and greater inhibition of MCF-7 cell lines [102]. Transcriptomic analysis revealed that intranasal immunization of CNs to mice induced cellular movement of lymphocytes, complement activation, fever, and production of cytokines within NALT [103]. Furthermore, intranasal immunization with chitosan alone could fully protect $\mathrm{BALB} / \mathrm{c}$ mice from a highly pathogenic $\mathrm{H} 7 \mathrm{~N} 9$ virus by stimulating the innate immune system. The significant infiltration of leukocytes and the levels of proinflammatory cytokines were observed in the lungs of immunized mice compared with those in untreated groups [104]. Mucosal immunity and protective efficacy of an intranasally delivered influenza vaccine was improved by CNs [81]. By using these immune-enhancing effects, $\mathrm{CNs}$ have been demonstrated as adjuvants for some antigens, including DNA [56,105], toxin [36], and ovalbumin [106], and could be vaccine candidates against Escherichia coli O157:H7 [107], Bacillus anthracis [57], Chlamydia psittaci [108], Mycobacterium tuberculosis [109,110], Brucella abortus [103,111,112], Hepatitis B virus [113,114], and influenza viruses [115,116].

\subsection{Chitosan Nanoparticles for Nasal Vaccines}

CNs have been used in mucosal delivery, especially in nasal delivery, as mucosal vaccine adjuvants in mice, rabbits, chickens, pigs, and cattle $[66,105,110,117-119]$. In several studies, intranasal immunization with CNs induced both cellular and humoral immune responses. In a study conducted 
by Li et al., a Chlamydia psittaci vaccine loaded with CNs induced Th1 immune responses in mice. They also compared the induction of mucosal immunity according to the immunization route of intranasal, intramuscular, and simultaneous immunization of antigen-loaded CNs. As expected, simultaneous immunization mediated stronger humoral responses to the intranasal and intramuscular immunization strategies alone, but nasal $\operatorname{IgA}$ and vaginal IgA levels were comparable to the intranasal route, suggesting that intranasal immunization has a more pronounced increase in humoral and mucosal immunity than intramuscular immunization [108].

The intranasally delivered CNs and Brucella abortus antigen in mice were found to induce mixed Th1/Th2 responses at 4 weeks post infection (wpi) and then finally to induce a Th2 response at 6 wpi [112]. Our previous studies revealed that malate dehydrogenase (Mdh), a promising B. abortus antigen, induced enhanced transport of Mdh when loaded in CNs in the in vitro M cell model and that CN-Mdh triggers signaling pathways of HMGB1, IL-6, and DC maturation within NALT in BALB/c mice [103,111]. Using these delivery systems, three B. abortus antigen (Mdh, Omp10, and Omp19)-loaded CNs elicited each antigen-specific IgA with a Th2-polarized immune response [120] (Figure 2). The combination of these highly immunogenic antigens elicited $\operatorname{IgG}$ specific to each type of antigen and IgA specific to the Mdh. Considering that the loading efficiency (LE) and release rate of antigen-loaded CNs were different based on the antigen, making a cocktail based on the property of each antigen-loaded CN will enhance the multiplicity of the antibody for mucosal and systemic immune responses.

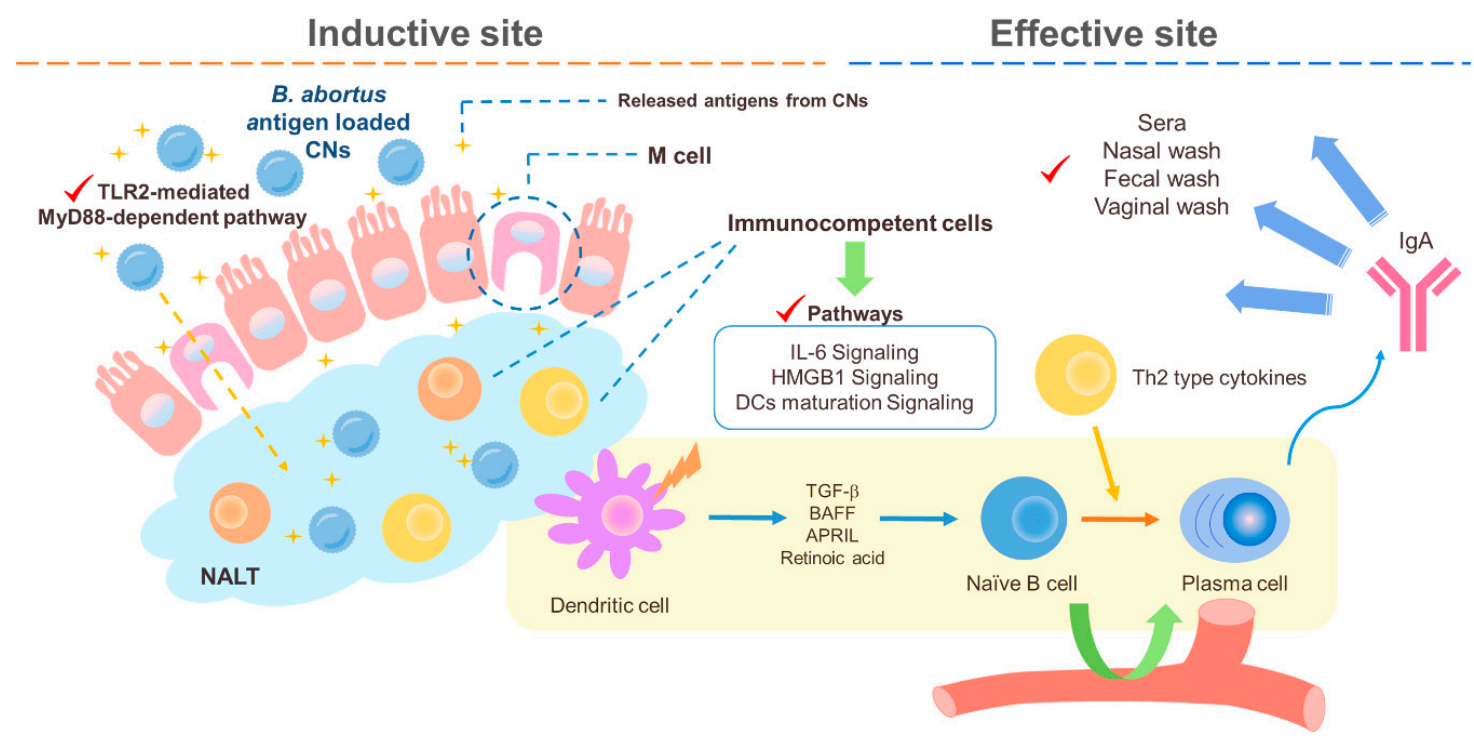

Figure 2. A schematic diagram of the suggested pathways of the immune response induced by B. abortus recombinant protein loaded CNs (chitosan nanoparticles). Loading B. abortus antigen, Mdh, into the CNs induced enhanced transport of Mdh in the in vitro $\mathrm{M}$ cell model and CNs-Mdh triggered activation of HMGB1, IL-6, and DCs maturation signaling within NALT in BALB/c mice and elicited Th2-related response with production of IgA at 6wpi (weeks post infection).

The Streptococcus equi extract with CNs or liposomes via nasal delivery induced both Th1 and Th2 responses [66]. Increased IgA in the lungs was significantly observed in the CN-loaded group, which is probably due to their different mucoadhesive properties. The delivery of $\mathrm{CN}$-loaded antigens has been shown to elicit specific mucosal immune responses in serum and in mucosal fluid, including nasal, saliva, bronchoalveolar lavage, lung, and vaginal secretions. Intranasal immunization with CNs loaded with DNA expressing the Streptococcus pneumoniae surface antigen A (PsaA) elicited enhanced mucosal and systemic antibody production compared with immunization with DNA alone [121]. CNs loaded with hemagglutinin (HA)-split influenza virus protein were shown to induce higher mucosal and systemic antibody titers than antigen alone [59]. 
Moreover, CNs promote antigen internalization by APCs and enhance the nasal residence time of an antigen. For instance, in a study that compared two nanoparticles, CNs and CNs plus alginate, as adjuvants for mast cell activator compound 48/80, nanoparticles of higher amounts of chitosan were better internalized by macrophages and dendritic cells and enhanced the residence time of C48/80 at the nasal membrane. The intranasal immunization of mice with Bacillus anthracis protective antigen (PA) adsorbed on C48/80 CNs elicited significant serum anti-PA antibodies and better balanced the Th1/Th2 profile compared to $\mathrm{CNs}$ plus alginate-C48/80 or $\mathrm{C} 48 / 80$ alone [118]. This observation correlated closely with the amount of chitosan, and the authors suggest that a reduced amount of chitosan could reduce mucoadhesive property, which may have hindered the uptake of the antigen. The recent studies in which CNs were used in nasal delivery are summarized in Table 3.

Table 3. Chitosan nanoparticles (CNs) for nasal vaccines.

\begin{tabular}{|c|c|c|c|c|c|c|c|}
\hline \multirow{2}{*}{ CNs } & \multirow{2}{*}{ Size $(\mathrm{nm})$} & \multirow{2}{*}{ Antigen } & \multirow{2}{*}{ LE (\%) } & \multirow{2}{*}{ Animal } & \multicolumn{2}{|c|}{ Immunoglobulin } & \multirow{2}{*}{ Ref } \\
\hline & & & & & $\operatorname{Ig} A$ & IgG & \\
\hline $\begin{array}{c}\text { Chitosan } \\
\text { nanoparticles }\end{array}$ & 276.1 & $\begin{array}{c}\text { Chlamydia psittaci } \\
\text { antigens }\end{array}$ & 71.7 & Mice & $\begin{array}{l}\text { Elicited (specific); } \\
\text { nasal wash and } \\
\text { vaginal secretions }\end{array}$ & $\begin{array}{c}\text { Elicited } \\
\text { (specific); } \\
\text { IgG1 } \\
\text { dominantly }\end{array}$ & [108] \\
\hline $\begin{array}{c}\text { Chitosan } \\
\text { nanoparticles }\end{array}$ & $\begin{array}{l}326.3 / \\
475.4 / \\
360.8 / \\
439.5\end{array}$ & $\begin{array}{l}\text { Brucella abortus } \\
\text { antigens }\end{array}$ & $\begin{array}{l}51 / 78 / \\
71 / 72\end{array}$ & Mice & $\begin{array}{c}\text { Elicited (specific); } \\
\text { nasal wash, fecal } \\
\text { wash, vaginal } \\
\text { secretions, and } \\
\text { serum }\end{array}$ & $\begin{array}{c}\text { Elicited } \\
\text { (Specific); } \\
\text { IgG1 } \\
\text { dominantly }\end{array}$ & [120] \\
\hline $\begin{array}{c}\text { Chitosan } \\
\text { nanoparticles }\end{array}$ & $350-400$ & $\begin{array}{l}\text { pHSP65pep gene } \\
\text { of Mycobacterium } \\
\text { tuberculosis }\end{array}$ & - & Mice & $\begin{array}{l}\text { Elicited (specific); } \\
\text { lung fluids }\end{array}$ & $\begin{array}{c}\text { Elicited } \\
\text { (Specific); } \\
\text { IgG2a } \\
\text { dominantly }\end{array}$ & [110] \\
\hline $\begin{array}{c}\text { Chitosan } \\
\text { nanoparticles }\end{array}$ & 500 & $\begin{array}{l}\text { Mast cell activator } \\
\text { compound } 48 / 80\end{array}$ & 18.65 & Mice & $\begin{array}{l}\text { Elicited (specific); } \\
\text { nasal wash, fecal } \\
\text { wash, vaginal } \\
\text { secretions, and } \\
\text { serum }\end{array}$ & $\begin{array}{c}\text { Elicited } \\
\text { (specific); } \\
\text { IgG1 } \\
\text { dominantly }\end{array}$ & [118] \\
\hline $\begin{array}{c}\text { Chitosan } \\
\text { nanoparticles }\end{array}$ & 571.7 & $\begin{array}{c}\text { Killed swine } \\
\text { influenza antigen }\end{array}$ & 67 & Swine & $\begin{array}{l}\text { Elicited (specific); } \\
\text { nasal wash, } \\
\text { bronchoalveolar } \\
\text { lavage fluids, and } \\
\text { lung lysates }\end{array}$ & $\begin{array}{l}\text { Elicited } \\
\text { (specific) }\end{array}$ & [81] \\
\hline $\begin{array}{c}\text { Chitosan } \\
\text { nanoparticles }\end{array}$ & 581.1 & $\begin{array}{l}\text { Influenza virus, } \\
\text { CpG } \\
\text { oligodeoxynucleotide, } \\
\text { and Quillaja } \\
\text { saponins }\end{array}$ & 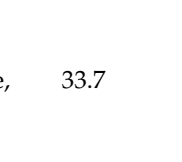 & Rabbit & $\begin{array}{l}\text { Elicited; nasal } \\
\text { washes }\end{array}$ & Elicited & [115] \\
\hline $\begin{array}{c}\text { Human serum } \\
\text { albumin conjugated } \\
\text { Chitosan } \\
\text { nanoparticles }\end{array}$ & 290 & $\begin{array}{l}\text { pCMVluc and } \\
\text { HBsAg gene of } \\
\text { hepatitis B virus }\end{array}$ & - & Mice & $\begin{array}{l}\text { Elicited (specific); } \\
\text { nasal wash and } \\
\text { vaginal secretions }\end{array}$ & $\begin{array}{l}\text { Elicited } \\
\text { (specific) }\end{array}$ & [113] \\
\hline $\begin{array}{c}\text { Chitosan/ } \\
\text { N-trimethyl- } \\
\text { aminoethyl- } \\
\text { methacrylate chitosan } \\
\text { (TMC) nanoparticles }\end{array}$ & 141.3/139.4 & $\begin{array}{l}\text { Influenza A H1N1 } \\
\text { antigen }\end{array}$ & $\begin{array}{c}88.5 / \\
\text { Approximately } \\
100\end{array}$ & Mice & $\begin{array}{l}\text { Elicited (specific); } \\
\text { nasal wash, saliva, } \\
\text { and lung wash }\end{array}$ & $\begin{array}{l}\text { Elicited } \\
\text { (specific) }\end{array}$ & [116] \\
\hline $\begin{array}{c}\text { TMC } \\
\text { nanoparticles }\end{array}$ & 365.2 & $\begin{array}{l}\text { E. coli O157:H7 } \\
\text { recombinant EIT }\end{array}$ & - & Mice & $\begin{array}{l}\text { Elicited (specific); } \\
\text { fecal wash, eye } \\
\text { wash, and serum }\end{array}$ & - & {$[60]$} \\
\hline
\end{tabular}


Table 3. Cont.

\begin{tabular}{|c|c|c|c|c|c|c|c|}
\hline \multirow{2}{*}{ CNs } & \multirow{2}{*}{ Size (nm) } & \multirow{2}{*}{ Antigen } & \multirow{2}{*}{ LE (\%) } & \multirow{2}{*}{ Animal } & \multicolumn{2}{|c|}{ Immunoglobulin } & \multirow{2}{*}{ Ref } \\
\hline & & & & & $\operatorname{Ig} A$ & IgG & \\
\hline $\begin{array}{c}\text { TMC liposome-based } \\
\text { nanoparticles }\end{array}$ & 280 & $\begin{array}{l}\text { B cell epitope } \\
\text { derived from } \\
\text { Group A } \\
\text { streptococcus } \\
\text { M-protein }\end{array}$ & 97 & Mice & $\begin{array}{l}\text { Elicited (specific); } \\
\text { saliva wash }\end{array}$ & $\begin{array}{l}\text { Elicited } \\
\text { (specific) }\end{array}$ & [122] \\
\hline $\begin{array}{c}\text { Chitosan-coated } \\
\text { PLGA nanoparticles }\end{array}$ & 819 & $\begin{array}{c}\text { Hepatitis B virus } \\
\text { surface antigen } \\
\text { (HBsAg) }\end{array}$ & $62-67$ & Chicken & $\begin{array}{l}\text { Elicited (specific); } \\
\text { Serum }\end{array}$ & $\begin{array}{l}\text { Elicited } \\
\text { (specific) }\end{array}$ & [114] \\
\hline $\begin{array}{l}\text { Curdlan } \\
\text { sulfate-O-(2-hydroxyl) } \\
\text { propyl-3-trimethyl } \\
\text { ammonium chitosan } \\
\text { chloride nanoparticles }\end{array}$ & 178 & Ovalbumin & 72.60 & Mice & $\begin{array}{l}\text { Elicited (specific); } \\
\text { saliva and vaginal } \\
\text { secretions }\end{array}$ & $\begin{array}{c}\text { Elicited } \\
\text { (specific); } \\
\text { IgG1 } \\
\text { dominantly }\end{array}$ & [106] \\
\hline $\begin{array}{l}\text { Mannosylated } \\
\text { chitosan } \\
\text { nanoparticles }\end{array}$ & 400 & $\begin{array}{l}\text { pPES gene of } \\
\text { Mycobacterium } \\
\text { tuberculosis }\end{array}$ & - & Mice & $\begin{array}{c}\text { Elicited (specific); } \\
\text { bronchoalveolar } \\
\text { lavage fluids }\end{array}$ & $\begin{array}{l}\text { Elicited } \\
\text { (specific) }\end{array}$ & [109] \\
\hline
\end{tabular}

\subsection{Application of Chitosan in Industry and Limitation of Using Cns Nasal Vaccines}

Currently, the polysaccharide is classified by U.S. FDA as Generally Recognized As Safe (GRAS) for food [123]. As for its derivative, to date, chitosan has been applied in food [124], cosmetics [125], textiles [126], contact lenses [127], wound healing [128], reduction of dental plaque formation [129], implants [130], and tissue engineering [131]. Specifically, chitosan has been used to prevent or treat wound and burn infections because it is antimicrobial, nontoxic, biocompatible, and is able to deliver extrinsic antimicrobial agents to wounds and burns [132]. As wound dressers, various chitosan-based products are commercially available in the market, including ChitoGauze ${ }^{\circledR}$ OTC, HemCon ${ }^{\circledR}$ Bandage, ChitoFlex ${ }^{\circledR}$ PRO, Chitodine ${ }^{\circledR}$, and Celox ${ }^{\mathrm{TM}}$. As CNs have many advantages including biocompatibility, encapsulation of antigens, stabilization, controlled release of antigens, wide range of applicable conditions, intracellular persistence in APCs, induction of systemic mucosal immunity, and suitability for intranasal immunization, several efforts are being made to develop antigen delivery systems using CNs. Nevertheless, evidence of the effect of their properties on clinical use remains lacking. CNs have some drawbacks including low solubility in neutral and alkaline $\mathrm{pH}$ [54], different preparation protocols according to the loading antigen, and difficulty in changing the pore size of nanoparticles [133]. To overcome these problems, several attempts such as changing DDA and molecular weight, adding derivatives, improving adhesiveness, and increasing circulation time in blood are feasible as long as the loaded antigen is stable. Although low toxicity in animal models is shown in chitosan, its real impact on the delivery system remains extremely limited. Further mechanistic studies and cooperation between researchers in materials science, immunology, and bioengineering are needed to determine the physicochemical properties of the specific antigen to be encapsulated and to apply $\mathrm{CNs}$ to their intranasal immunization as vaccine adjuvants.

Author Contributions: Writing-original draft preparation and editing, S.S.; writing-review and editing, S.S., H.S.Y. All authors have read and agreed to the published version of the manuscript.

Funding: This work was supported by “Cooperative Research Program of Center for Companion Animal Research (Project NO. PJ013985)" Rural Development Administration, Korea, the Brain Korea (BK) 21 FOUR Future Veterinary Medicine Leading Education and Research Center, and the Research Institute of Veterinary Science, Seoul National University, Korea.

Conflicts of Interest: The authors declare no conflict of interest. 


\section{References}

1. Neutra, M.R.; Kozlowski, P.A. Mucosal Vaccines: The Promise and the Challenge. Nat. Rev. Immunol. 2006, 6, 148-158. [CrossRef]

2. Hiroi, T.; Iwatani, K.; Iijima, H.; Kodama, S.; Yanagita, M.; Kiyono, H. Nasal Immune System: Distinctive Th0 and Th1/Th2 Type Environments in Murine Nasal-Associated Lymphoid Tissues and Nasal Passage, Respectively. Eur. J. Immunol. 1998, 28, 3346-3353. [CrossRef]

3. Brandtzaeg, P. Secretory Iga: Designed for Anti-Microbial Defense. Front. Immunol. 2013, 4, 222. [CrossRef]

4. Date, Y.; Ebisawa, M.; Fukuda, S.; Shima, H.; Obata, Y.; Takahashi, D.; Kato, T.; Hanazato, M.; Nakato, G.; Williams, I.R.; et al. Nalt M Cells Are Important for Immune Induction for the Common Mucosal Immune System. Int. Immunol. 2017, 29, 471-478. [CrossRef] [PubMed]

5. Lamichhane, A.; Tatsuhiko, A.; Hiroshi, K. The Mucosal Immune System for Vaccine Development. Vaccine 2014, 32, 6711-6723. [CrossRef] [PubMed]

6. Peluso, G.; Petillo, O.; Ranieri, M.; Santin, M.; Ambrosio, L.; Calabro, D.; Avallone, B.; Balsamo, G. Chitosan-Mediated Stimulation of Macrophage Function. Biomaterials 1994, 15, 1215-1220. [CrossRef]

7. Seferian, P.G.; Martinez, M.L. Immune Stimulating Activity of Two New Chitosan Containing Adjuvant Formulations. Vaccine 2000, 19, 661-668. [CrossRef]

8. Singh, B.; Sushila, M.; Princy, S.; Ki-Hyun, C.; Yun-Jaie, C.; Chong-Su, C. Needle-Free Immunization with Chitosan-Based Systems. Int. J. Mol. Sci. 2018, 19, 3639. [CrossRef]

9. Otczyk, D.C.; Cripps, A.W. Mucosal Immunization: A Realistic Alternative. Hum. Vaccin. 2010, 6, 978-1006. [CrossRef]

10. Bemark, M.; Boysen, P.; Lycke, N.Y. Induction of Gut Iga Production through T Cell-Dependent and T Cell-Independent Pathways. Ann. N. Y. Acad. Sci. 2012, 1247, 97-116. [CrossRef]

11. Corr, S.C.; Gahan, C.C.; Hill, C. M-Cells: Origin, Morphology and Role in Mucosal Immunity and Microbial Pathogenesis. FEMS Immunol. Med. Microbiol. 2008, 52, 2-12. [CrossRef] [PubMed]

12. Kerneis, S.; Bogdanova, A.; Kraehenbuhl, J.P.; Pringault, E. Conversion by Peyer's Patch Lymphocytes of Human Enterocytes into M Cells That Transport Bacteria. Science 1997, 277, 949-952. [CrossRef] [PubMed]

13. Kiyono, H.; Fukuyama, S. Nalt- Versus Peyer's-Patch-Mediated Mucosal Immunity. Nat. Rev. Immunol. 2004, 4, 699-710. [CrossRef] [PubMed]

14. Sato, A.; Iwasaki, A. Peyer's Patch Dendritic Cells as Regulators of Mucosal Adaptive Immunity. Cell Mol. Life Sci. 2005, 62, 1333-1338. [CrossRef] [PubMed]

15. Fagarasan, S.; Kawamoto, S.; Kanagawa, O.; Suzuki, K. Adaptive Immune Regulation in the Gut: T Cell-Dependent and T Cell-Independent Iga Synthesis. Annu. Rev. Immunol. 2010, 28, 243-273. [CrossRef]

16. Mora, J.R.; Iwata, M.; Eksteen, B.; Song, S.-Y.; Junt, T.; Senman, B.; Otipoby, K.L.; Yokota, A.; Takeuchi, H.; Ricciardi-Castagnoli, P.; et al. Generation of Gut-Homing Iga-Secreting B Cells by Intestinal Dendritic Cells. Science 2006, 314, 1157-1160. [CrossRef]

17. Kim, D.Y.; Sato, A.; Fukuyama, S.; Sagara, H.; Nagatake, T.; Kong, I.G.; Goda, K.; Nochi, T.; Kunisawa, J.; Sato, S.; et al. The Airway Antigen Sampling System: Respiratory M Cells as an Alternative Gateway for Inhaled Antigens. J. Immunol. 2011, 186, 4253-4262. [CrossRef]

18. Mora, J.R.; Von Andrian, U.H. Differentiation and Homing of Iga-Secreting Cells. Mucosal. Immunol. 2008, 1, 96-109. [CrossRef]

19. Kunkel, E.J.; Butcher, E.C. Plasma-Cell Homing. Nat. Rev. Immunol. 2003, 3, 822-829. [CrossRef]

20. Takaki, H.; Ichimiya, S.; Matsumoto, M.; Seya, T. Mucosal Immune Response in Nasal-Associated Lymphoid Tissue Upon Intranasal Administration by Adjuvants. J. Innate Immun. 2018, 10, 515-521. [CrossRef]

21. Lycke, N. Recent Progress in Mucosal Vaccine Development: Potential and Limitations. Nat. Rev. Immunol. 2012, 12, 592-605. [CrossRef] [PubMed]

22. Pedersen, G.; Cox, R. The Mucosal Vaccine Quandary: Intranasal vs. Sublingual Immunization against Influenza. Hum. Vaccines Immunother. 2012, 8, 689-693. [CrossRef] [PubMed]

23. Kunkel, E.J.; Kim, C.H.; Lazarus, N.H.; Vierra, M.A.; Soler, D.; Bowman, E.P.; Butcher, E.C. Ccr10 Expression Is a Common Feature of Circulating and Mucosal Epithelial Tissue Iga Ab-Secreting Cells. J. Clin. Investig. 2003, 111, 1001-1010. [CrossRef] [PubMed]

24. Mestecky, J. The Common Mucosal Immune System and Current Strategies for Induction of Immune Responses in External Secretions. J. Clin. Immunol. 1987, 7, 265-276. [CrossRef] 
25. Kaetzel, C.S.; Robinson, J.K.; Chintalacharuvu, K.R.; Vaerman, J.P.; Lamm, M.E. The Polymeric Immunoglobulin Receptor (Secretory Component) Mediates Transport of Immune Complexes across Epithelial Cells: A Local Defense Function for Iga. Proc. Natl. Acad. Sci. USA 1991, 88, 8796-8800. [CrossRef]

26. Tiwari, G.; Tiwari, R.; Sriwastawa, B.; Bhati, L.; Pandey, S.; Pandey, P.; Bannerjee, S.K. Drug Delivery Systems: An Updated Review. Int. J. Pharm. Investig. 2012, 2, 2-11. [CrossRef]

27. Zaman, M.; Chandrudu, S.; Toth, I. Strategies for Intranasal Delivery of Vaccines. Drug Deliv. Transl. Res. 2013, 3, 100-109. [CrossRef]

28. Kim, S.H.; Lee, K.Y.; Jang, Y.S. Mucosal Immune System and M Cell-Targeting Strategies for Oral Mucosal Vaccination. Immune Netw. 2012, 12, 165-175. [CrossRef]

29. Hussain, A.; Ahsan, F. The Vagina as a Route for Systemic Drug Delivery. J. Control. Release 2005, 103, 301-313. [CrossRef]

30. Yin, L.T.; Hao, H.X.; Wang, H.L.; Zhang, J.H.; Meng, X.L.; Yin, G.R. Intranasal Immunisation with Recombinant Toxoplasma Gondii Actin Partly Protects Mice against Toxoplasmosis. PLoS ONE 2013, 8, e82765. [CrossRef]

31. Rudin, A.; Johansson, E.L.; Bergquist, C.; Holmgren, J. Differential Kinetics and Distribution of Antibodies in Serum and Nasal and Vaginal Secretions after Nasal and Oral Vaccination of Humans. Infect. Immun. 1998, 66, 3390-3396. [CrossRef] [PubMed]

32. Suman, J.D. Nasal Drug Delivery. Expert Opin. Biol. Ther. 2003, 3, 519-523. [CrossRef] [PubMed]

33. Chen, L.; Wang, J.; Zganiacz, A.; Xing, Z. Single Intranasal Mucosal Mycobacterium Bovis Bcg Vaccination Confers Improved Protection Compared to Subcutaneous Vaccination against Pulmonary Tuberculosis. Infect. Immun. 2004, 72, 238-246. [CrossRef] [PubMed]

34. Giri, P.K.; Sable, S.B.; Verma, I.; Khuller, G.K. Comparative Evaluation of Intranasal and Subcutaneous Route of Immunization for Development of Mucosal Vaccine against Experimental Tuberculosis. FEMS Immunol. Med. Microbiol. 2005, 45, 87-93. [CrossRef] [PubMed]

35. Kharb, S.; Charan, S. Mucosal Immunization Provides Better Protection Than Subcutaneous Immunization against Pasteurella Multocida (B:2) in Mice Preimmunized with the Outer Membrane Proteins. Vet. Res. Commun. 2011, 35, 457-461. [CrossRef] [PubMed]

36. Kang, M.L.; Kang, S.G.; Jiang, H.L.; Shin, S.W.; Lee, D.Y.; Ahn, J.M.; Rayamahji, N.; Park, I.K.; Shin, S.J.; Cho, C.S.; et al. In Vivo Induction of Mucosal Immune Responses by Intranasal Administration of Chitosan Microspheres Containing Bordetella Bronchiseptica Dnt. Eur. J. Pharm. Biopharm. 2006, 63, 215-220. [CrossRef]

37. Quinones, J.P.; Peniche, H.; Peniche, C. Chitosan Based Self-Assembled Nanoparticles in Drug Delivery. Polymers 2018, 10, 235. [CrossRef]

38. Sercombe, L.; Veerati, T.; Moheimani, F.; Wu, S.Y.; Sood, A.K.; Hua, S. Advances and Challenges of Liposome Assisted Drug Delivery. Front. Pharmacol. 2015, 6, 286. [CrossRef]

39. Ho, C.C.; Luo, Y.H.; Chuang, T.H.; Yang, C.S.; Ling, Y.C.; Lin, P. Quantum Dots Induced Monocyte Chemotactic Protein-1 Expression Via Myd88-Dependent Toll-Like Receptor Signaling Pathways in Macrophages. Toxicology 2013, 308, 1-9. [CrossRef]

40. Shah, R.R.; O'Hagan, D.T.; Amiji, M.M.; Brito, L.A. The Impact of Size on Particulate Vaccine Adjuvants. Nanomedicine 2014, 9, 2671-2681. [CrossRef]

41. Dimov, N.; Kastner, E.; Hussain, M.; Perrie, Y.; Szita, N. Formation and Purification of Tailored Liposomes for Drug Delivery Using a Module-Based Micro Continuous-Flow System. Sci. Rep. 2017, 7, 12045. [CrossRef] [PubMed]

42. des Rieux, A.; Fievez, V.; Garinot, M.; Schneider, Y.J.; Preat, V. Nanoparticles as Potential Oral Delivery Systems of Proteins and Vaccines: A Mechanistic Approach. J. Control. Release 2006, 116, 1-27. [CrossRef]

43. Lai, S.K.; O'Hanlon, D.E.; Harrold, S.; Man, S.T.; Wang, Y.Y.; Cone, R.; Hanes, J. Rapid Transport of Large Polymeric Nanoparticles in Fresh Undiluted Human Mucus. Proc. Natl. Acad. Sci. USA 2007, 104, 1482-1487. [CrossRef]

44. Elias, D.R.; Poloukhtine, A.; Popik, V.; Tsourkas, A. Effect of Ligand Density, Receptor Density, and Nanoparticle Size on Cell Targeting. Nanomedicine 2013, 9, 194-201. [CrossRef]

45. Lim, J.S.; Na, H.S.; Lee, H.C.; Choy, H.E.; Park, S.C.; Han, J.M.; Cho, K.A. Caveolae-Mediated Entry of Salmonella Typhimurium in a Human M-Cell Model. Biochem. Biophys. Res. Commun. 2009, 390, 1322-1327. [CrossRef] [PubMed] 
46. Green, B.T.; Brown, D.R. Differential Effects of Clathrin and Actin Inhibitors on Internalization of Escherichia Coli and Salmonella Choleraesuis in Porcine Jejunal Peyer's Patches. Vet. Microbiol. 2006, 113, 117-122. [CrossRef]

47. Kyd, J.M.; Cripps, A.W. Functional Differences between M Cells and Enterocytes in Sampling Luminal Antigens. Vaccine 2008, 26, 6221-6224. [CrossRef] [PubMed]

48. Chang, H.; Ho, C.C.; Yang, C.S.; Chang, W.H.; Tsai, M.H.; Tsai, H.T.; Lin, P. Involvement of Myd88 in Zinc Oxide Nanoparticle-Induced Lung Inflammation. Exp. Toxicol. Pathol. 2013, 65, 887-896. [CrossRef] [PubMed]

49. Chen, P.; Kanehira, K.; Taniguchi, A. Role of Toll-Like Receptors 3, 4 and 7 in Cellular Uptake and Response to Titanium Dioxide Nanoparticles. Sci. Technol. Adv. Mater. 2013, 14, 015008. [CrossRef]

50. Lucarelli, M.; Gatti, A.M.; Savarino, G.; Quattroni, P.; Martinelli, L.; Monari, E.; Boraschi, D. Innate Defence Functions of Macrophages Can Be Biased by Nano-Sized Ceramic and Metallic Particles. Eur. Cytokine Netw. 2004, 15, 339-346.

51. Luo, Y.H.; Chang, L.W.; Lin, P. Metal-Based Nanoparticles and the Immune System: Activation, Inflammation, and Potential Applications. Biomed. Res. Int. 2015, 2015. [CrossRef] [PubMed]

52. Lapthorne, S.; Macsharry, J.; Scully, P.; Nally, K.; Shanahan, F. Differential Intestinal M-Cell Gene Expression Response to Gut Commensals. Immunology 2012, 136, 312-324. [CrossRef] [PubMed]

53. Zaman, M.; Chandrudu, S.; Giddam, A.K.; Reiman, J.; Skwarczynski, M.; McPhun, V.; Moyle, P.M.; Batzloff, M.R.; Good, M.F.; Toth, I. Group a Streptococcal Vaccine Candidate: Contribution of Epitope to Size, Antigen Presenting Cell Interaction and Immunogenicity. Nanomedicine 2014, 9, 2613-2624. [CrossRef] [PubMed]

54. Mohammed, M.A.; Syeda, J.T.M.; Wasan, K.M.; Wasan, E.K. An Overview of Chitosan Nanoparticles and Its Application in Non-Parenteral Drug Delivery. Pharmaceutics 2017, 9, 53. [CrossRef]

55. Song, S.; Jin, X.; Zhang, L.; Zhao, C.; Ding, Y.; Ang, Q.; Khaidav, O.; Shen, C. Pegylated and Cd47-Conjugated Nanoellipsoidal Artificial Antigen-Presenting Cells Minimize Phagocytosis and Augment Anti-Tumor T-Cell Responses. Int. J. Nanomed. 2019, 14, 2465-2483. [CrossRef]

56. Gong, Q.; Kong, L.Y.; Niu, M.F.; Qin, C.L.; Yang, Y.; Li, X.; Ruan, M.D.; Tian, Y.; Li, Z.L. Construction of a Ptfa Chitosan Nanoparticle DNA Vaccine against Pasteurella Multocida and the Immune Response in Chickens. Vet. J. 2018, 231, 1-7. [CrossRef]

57. Malik, A.; Gupta, M.; Mani, R.; Gogoi, H.; Bhatnagar, R. Trimethyl Chitosan Nanoparticles Encapsulated Protective Antigen Protects the Mice against Anthrax. Front. Immunol. 2018, 9, 562. [CrossRef]

58. Lopes, P.D.; Okino, C.H.; Fernando, F.S.; Pavani, C.; Casagrande, V.M.; Lopez, R.F.V.; Montassier, M.F.S.; Montassier, H.J. Inactivated Infectious Bronchitis Virus Vaccine Encapsulated in Chitosan Nanoparticles Induces Mucosal Immune Responses and Effective Protection against Challenge. Vaccine 2018, 36, 2630-2636. [CrossRef]

59. Sawaengsak, C.; Mori, Y.; Yamanishi, K.; Mitrevej, A.; Sinchaipanid, N. Chitosan Nanoparticle Encapsulated Hemagglutinin-Split Influenza Virus Mucosal Vaccine. AAPS PharmSciTech 2014, 15, 317-325. [CrossRef]

60. Khanifar, J.; Salmanian, A.H.; Hosseini, R.H.; Amani, J.; Kazemi, R. Chitosan Nano-Structure Loaded with Recombinant E. Coli O157:H7 Antigens as a Vaccine Candidate Can Effectively Increase Immunization Capacity. Artif. Cells Nanomed. Biotechnol. 2019, 47, 2593-2604. [CrossRef]

61. Margaroni, M.; Agallou, M.; Athanasiou, E.; Kammona, O.; Kiparissides, C.; Gaitanaki, C.; Karagouni, E. Vaccination with Poly(D,L-Lactide-Co-Glycolide) Nanoparticles Loaded with Soluble Leishmania Antigens and Modified with a Tnf $\alpha$-Mimicking Peptide or Monophosphoryl Lipid a Confers Protection against Experimental Visceral Leishmaniasis. Int. J. Nanomed. 2017, 12, 6169-6184. [CrossRef] [PubMed]

62. Manish, M.; Rahi, A.; Kaur, M.; Bhatnagar, R.; Singh, S. A Single-Dose Plga Encapsulated Protective Antigen Domain 4 Nanoformulation Protects Mice against Bacillus Anthracis Spore Challenge. PLoS ONE 2013, 8, e61885. [CrossRef] [PubMed]

63. Chahal, J.S.; Khan, O.F.; Cooper, C.L.; McPartlan, J.S.; Tsosie, J.K.; Tilley, L.D.; Sidik, S.M.; Lourido, S.; Langer, R.; Bavari, S.; et al. Dendrimer-Rna Nanoparticles Generate Protective Immunity against Lethal Ebola, H1n1 Influenza, and Toxoplasma Gondii Challenges with a Single Dose. Proc. Natl. Acad. Sci. USA 2016, 113, E4133-E4142. [CrossRef] [PubMed] 
64. Lee, Y.T.; Ko, E.J.; Hwang, H.S.; Lee, J.S.; Kim, K.H.; Kwon, Y.M.; Kang, S.M. Respiratory Syncytial Virus-Like Nanoparticle Vaccination Induces Long-Term Protection without Pulmonary Disease by Modulating Cytokines and T-Cells Partially through Alveolar Macrophages. Int. J. Nanomed. 2015, 10, 4491-4505.

65. Marasini, N.; Giddam, A.K.; Ghaffar, K.A.; Batzloff, M.R.; Good, M.F.; Skwarczynski, M.; Toth, I. Multilayer Engineered Nanoliposomes as a Novel Tool for Oral Delivery of Lipopeptide-Based Vaccines against Group a Streptococcus. Nanomedicine 2016, 11, 1223-1236. [CrossRef] [PubMed]

66. Figueiredo, L.; Cadete, A.; Gonçalves, L.M.; Corvo, M.L.; Almeida, A.J. Intranasal Immunisation of Mice against Streptococcus Equi Using Positively Charged Nanoparticulate Carrier Systems. Vaccine 2012, 30, 6551-6558. [CrossRef]

67. Dhakal, S.; Cheng, X.; Salcido, J.; Renu, S.; Bondra, K.; Lakshmanappa, Y.S.; Misch, C.; Ghimire, S.; Feliciano-Ruiz, N.; Hogshead, B.; et al. Liposomal Nanoparticle-Based Conserved Peptide Influenza Vaccine and Monosodium Urate Crystal Adjuvant Elicit Protective Immune Response in Pigs. Int. J. Nanomed. 2018, 13, 6699-6715. [CrossRef]

68. Tada, R.; Hidaka, A.; Iwase, N.; Takahashi, S.; Yamakita, Y.; Iwata, T.; Muto, S.; Sato, E.; Takayama, N.; Honjo, E.; et al. Intranasal Immunization with Dotap Cationic Liposomes Combined with Dc-Cholesterol Induces Potent Antigen-Specific Mucosal and Systemic Immune Responses in Mice. PLoS ONE 2015, 10, e0139785. [CrossRef]

69. Cheng, J.; Wen, S.; Wang, S.; Hao, P.; Cheng, Z.; Liu, Y.; Zhao, P.; Liu, J. Gp85 Protein Vaccine Adjuvanted with Silica Nanoparticles against Alv-J in Chickens. Vaccine 2017, 35, 293-298. [CrossRef]

70. Neuhaus, V.; Chichester, J.A.; Ebensen, T.; Schwarz, K.; Hartman, C.E.; Shoji, Y.; Guzmán, C.A.; Yusibov, V.; Sewald, K.; Braun, A. A New Adjuvanted Nanoparticle-Based H1n1 Influenza Vaccine Induced Antigen-Specific Local Mucosal and Systemic Immune Responses after Administration into the Lung. Vaccine 2014, 32, 3216-3222. [CrossRef]

71. Tao, W.; Hurst, B.L.; Shakya, A.K.; Uddin, M.J.; Ingrole, R.S.; Hernandez-Sanabria, M.; Arya, R.P.; Bimler, L.; Paust, S.; Tarbet, E.B.; et al. Consensus M2e Peptide Conjugated to Gold Nanoparticles Confers Protection against H1n1, H3n2 and H5n1 Influenza a Viruses. Antiviral Res. 2017, 141, 62-72. [CrossRef]

72. Sanchez-Villamil, J.I.; Tapia, D.; Torres, A.G. Development of a Gold Nanoparticle Vaccine against Enterohemorrhagic Escherichia Coli O157:H7. mBio 2019, 10, 4. [CrossRef] [PubMed]

73. Biswaro, L.S.; Sousa, M.G.d.; Rezende, T.M.B.; Dias, S.C.; Franco, O.L. Antimicrobial Peptides and Nanotechnology, Recent Advances and Challenges. Front. Microbiol. 2018, 9, 855. [CrossRef] [PubMed]

74. Sun, B.; Zhang, M.; Shen, J.; He, Z.; Fatehi, P.; Ni, Y. Applications of Cellulose-Based Materials in Sustained Drug Delivery Systems. Curr. Med. Chem. 2019, 26, 2485-2501. [CrossRef] [PubMed]

75. Amin, M.K.; Boateng, J.S. Comparison and Process Optimization of Plga, Chitosan and Silica Nanoparticles for Potential Oral Vaccine Delivery. Ther. Deliv. 2019, 10, 493-514. [CrossRef]

76. Rassu, G.; Porcu, E.P.; Fancello, S.; Obinu, A.; Senes, N.; Galleri, G.; Migheli, R.; Gavini, E.; Giunchedi, P. Intranasal Delivery of Genistein-Loaded Nanoparticles as a Potential Preventive System against Neurodegenerative Disorders. Pharmaceutics 2018, 11, 8. [CrossRef]

77. Muzzarelli, R.A. Human Enzymatic Activities Related to the Therapeutic Administration of Chitin Derivatives. Cell. Mol. Life Sci. CMLS 1997, 53, 131-140. [CrossRef]

78. Verheul, R.J.; Amidi, M.; van der Wal, S.; van Riet, E.; Jiskoot, W.; Hennink, W.E. Synthesis, Characterization and in Vitro Biological Properties of O-Methyl Free N,N,N-Trimethylated Chitosan. Biomaterials 2008, 29, 3642-3649. [CrossRef]

79. Bigucci, F.; Abruzzo, A.; Vitali, B.; Saladini, B.; Cerchiara, T.; Gallucci, M.C.; Luppi, B. Vaginal Inserts Based on Chitosan and Carboxymethylcellulose Complexes for Local Delivery of Chlorhexidine: Preparation, Characterization and Antimicrobial Activity. Int. J. Pharm. 2015, 478, 456-463. [CrossRef]

80. Bigucci, F.; Abruzzo, A.; Saladini, B.; Gallucci, M.C.; Cerchiara, T.; Luppi, B. Development and Characterization of Chitosan/Hyaluronan Film for Transdermal Delivery of Thiocolchicoside. Carbohydr. Polym. 2015, 130, 32-40. [CrossRef]

81. Dhakal, S.; Renu, S.; Ghimire, S.; Lakshmanappa, Y.S.; Hogshead, B.T.; Feliciano-Ruiz, N.; Lu, F.; HogenEsch, H.; Krakowka, S.; Lee, C.W.; et al. Renukaradhya. Mucosal Immunity and Protective Efficacy of Intranasal Inactivated Influenza Vaccine Is Improved by Chitosan Nanoparticle Delivery in Pigs. Front. Immunol. 2018, 9, 934. [CrossRef] [PubMed] 
82. Ali, S.S.; Kenawy, E.R.; Sonbol, F.I.; Sun, J.; Al-Etewy, M.; Ali, A.; Huizi, L.; El-Zawawy, A.N. Pharmaceutical Potential of a Novel Chitosan Derivative Schiff Base with Special Reference to Antibacterial, Anti-Biofilm, Antioxidant, Anti-Inflammatory, Hemocompatibility and Cytotoxic Activities. Pharm. Res. 2018, 36, 5. [CrossRef]

83. Al-Nemrawi, N.K.; Okour, A.R.; Dave, R.H. Surface Modification of Plga Nanoparticles Using Chitosan: Effect of Molecular Weight, Concentration, and Degree of Deacetylation. Adv. Polym. Tech. 2018, 37, 3066-3075. [CrossRef]

84. Grenha, A. Chitosan Nanoparticles: A Survey of Preparation Methods. J. Drug Target. 2012, 20, $291-300$. [CrossRef] [PubMed]

85. Dash, M.; Chiellini, F.; Ottenbrite, R.M.; Chiellini, E. Chitosan-A Versatile Semi-Synthetic Polymer in Biomedical Applications. Prog. Polym. Sci. 2011, 36, 981-1014. [CrossRef]

86. Sreekumar, S.; Goycoolea, F.M.; Moerschbacher, B.M.; Rivera-Rodriguez, G.R. Parameters Influencing the Size of Chitosan-Tpp Nano- and Microparticles. Sci. Rep. 2018, 8, 4695. [CrossRef]

87. George, M.; Abraham, T.E. Polyionic Hydrocolloids for the Intestinal Delivery of Protein Drugs: Alginate and Chitosan-A Review. J. Control. Release 2006, 114, 1-14. [CrossRef]

88. Deacon, M.P.; Mcgurk, S.; Roberts, C.J.; Williams, P.M.; Tendler, S.J.; Davies, M.C.; Davis, S.S.; Harding, S.E. Atomic Force Microscopy of Gastric Mucin and Chitosan Mucoadhesive Systems. Biochem. J. 2000, 348, 557-563. [CrossRef]

89. Lehr, C.-M.; Bouwstra, J.A.; Schacht, E.H.; Junginger, H.E. In Vitro Evaluation of Mucoadhesive Properties of Chitosan and Some Other Natural Polymers. Int. J. Pharm. 1992, 78, 43-48. [CrossRef]

90. He, P.; Davis, S.S.; Illum, L. In Vitro Evaluation of the Mucoadhesive Properties of Chitosan Microspheres. Int. J. Pharm. 1998, 166, 75-88. [CrossRef]

91. Qinna, N.A.; Karwi, Q.G.; Al-Jbour, N.; Al-Remawi, M.A.; Alhussainy, T.M.; Al-So'ud, K.A.; al Omari, M.M.; Badwan, A.A. Influence of Molecular Weight and Degree of Deacetylation of Low Molecular Weight Chitosan on the Bioactivity of Oral Insulin Preparations. Mar. Drugs 2015, 13, 1710-1725. [CrossRef] [PubMed]

92. Zhang, S.; Li, J.; Lykotrafitis, G.; Bao, G.; Suresh, S. Size-Dependent Endocytosis of Nanoparticles. Adv. Mater. 2009, 21, 419-424. [CrossRef] [PubMed]

93. Pérez-Campaña, C.; Gómez-Vallejo, V.; Puigivila, M.; Martín, A.; Calvo-Fernández, T.; Moya, S.E.; Ziolo, R.F.; Reese, T.; Llop, J. Biodistribution of Different Sized Nanoparticles Assessed by Positron Emission Tomography: A General Strategy for Direct Activation of Metal Oxide Particles. ACS Nano 2013, 7, 3498-3505. [CrossRef] [PubMed]

94. Jesus, S.; Marques, A.P.; Duarte, A.; Soares, E.; Costa, J.P.; Colaço, M.; Schmutz, M.; Som, C.; Borchard, G.; Wick, P.; et al. Chitosan Nanoparticles: Shedding Light on Immunotoxicity and Hemocompatibility. Front. Bioeng. Biotechnol. 2020, 8, 100. [CrossRef] [PubMed]

95. Kulkarni, A.D.; Vanjari, Y.H.; Sancheti, K.H.; Patel, H.M.; Belgamwar, V.S.; Surana, S.J.; Pardeshi, C.V. New Nasal Nanocomplex Self-Assembled from Charged Biomacromolecules: N,N,N-Trimethyl Chitosan and Dextran Sulfate. Int. J. Biol. Macromol. 2016, 88, 476-490. [CrossRef] [PubMed]

96. Yue, Z.G.; Wei, W.; Lv, P.P.; Yue, H.; Wang, L.Y.; Su, Z.G.; Ma, G.H. Surface Charge Affects Cellular Uptake and Intracellular Trafficking of Chitosan-Based Nanoparticles. Biomacromolecules 2011, 12, 2440-2446. [CrossRef] [PubMed]

97. Mangal, S.; Pawar, D.; Garg, N.K.; Jain, A.K.; Vyas, S.P.; Rao, D.S.; Jaganathan, K.S. Pharmaceutical and Immunological Evaluation of Mucoadhesive Nanoparticles Based Delivery System(S) Administered Intranasally. Vaccine 2011, 29, 4953-4962. [CrossRef]

98. Shibata, Y.; Foster, L.A.; Metzger, W.J.; Myrvik, Q.N. Alveolar Macrophage Priming by Intravenous Administration of Chitin Particles, Polymers of N-Acetyl-D-Glucosamine, in Mice. Infect. Immun. 1997, 65, 1734-1741. [CrossRef]

99. Nevagi, R.J.; Khalil, Z.G.; Hussein, W.M.; Powell, J.; Batzloff, M.R.; Capon, R.J.; Good, M.F.; Skwarczynski, M.; Toth, I. Polyglutamic Acid-Trimethyl Chitosan-Based Intranasal Peptide Nano-Vaccine Induces Potent Immune Responses against Group a Streptococcus. Acta Biomater. 2018, 80, 278-287. [CrossRef]

100. Durán-Lobato, M.; Martín-Banderas, L.; Gonçalves, L.M.; Fernández-Arévalo, M.; Almeida, A.J. Comparative Study of Chitosan- and Peg-Coated Lipid and Plga Nanoparticles as Oral Delivery Systems for Cannabinoids. J. Nanopart. Res. 2015, 17, 61. [CrossRef] 
101. Siahkamari, M.; Jamali, A.; Sabzevari, A.; Shakeri, A. Removal of Lead(Ii) Ions from Aqueous Solutions Using Biocompatible Polymeric Nano-Adsorbents: A Comparative Study. Carbohydr. Polym. 2017, 157, 1180-1189. [CrossRef]

102. Deb, A.; Vimala, R. Natural and Synthetic Polymer for Graphene Oxide Mediated Anticancer Drug Delivery-a Comparative Study. Int. J. Biol. Macromol. 2018, 107, 2320-2333. [CrossRef] [PubMed]

103. Shim, S.; Soh, S.H.; Im, Y.B.; Ahn, C.; Park, H.T.; Park, H.E.; Park, W.B.; Kim, S.; Yoo, H.S. Induction of Systemic Immunity through Nasal-Associated Lymphoid Tissue (Nalt) of Mice Intranasally Immunized with Brucella Abortus Malate Dehydrogenase-Loaded Chitosan Nanoparticles. PLoS ONE 2020, 15, e0228463. [CrossRef] [PubMed]

104. Zheng, M.; Qu, D.; Wang, H.; Sun, Z.; Liu, X.; Chen, J.; Li, C.; Li, X.; Chen, Z. Intranasal Administration of Chitosan against Influenza a (H7n9) Virus Infection in a Mouse Model. Sci. Rep. 2016, 6, 28729. [CrossRef] [PubMed]

105. Pan, L.; Zhang, Z.; Lv, J.; Zhou, P.; Hu, W.; Fang, Y.; Chen, H.; Liu, X.; Shao, J.; Zhao, F.; et al. Induction of Mucosal Immune Responses and Protection of Cattle against Direct-Contact Challenge by Intranasal Delivery with Foot-and-Mouth Disease Virus Antigen Mediated by Nanoparticles. Int. J. Nanomed. 2014, 9 , 5603-5618. [CrossRef] [PubMed]

106. Zhang, S.; Huang, S.; Lu, L.; Song, X.; Li, P.; Wang, F. Curdlan Sulfate-O-Linked Quaternized Chitosan Nanoparticles: Potential Adjuvants to Improve the Immunogenicity of Exogenous Antigens Via Intranasal Vaccination. Int. J. Nanomed. 2018, 13, 2377-2394. [CrossRef] [PubMed]

107. Doavi, T.; Mousavi, S.L.; Kamali, M.; Amani, J.; Ramandi, M.F. Chitosan-Based Intranasal Vaccine against Escherichia coli O157:H7. Ir. Biomed. J. 2016, 20, 97-108.

108. Li, Y.; Wang, C.; Sun, Z.; Xiao, J.; Yan, X.; Chen, Y.; Yu, J.; Wu, Y. Simultaneous Intramuscular and Intranasal Administration of Chitosan Nanoparticles-Adjuvanted Chlamydia Vaccine Elicits Elevated Protective Responses in the Lung. Int. J. Nanomed. 2019, 14, 8179-8193. [CrossRef]

109. Wu, M.; Zhao, H.; Li, M.; Yue, Y.; Xiong, S.; Xu, W. Intranasal Vaccination with Mannosylated Chitosan Formulated DNA Vaccine Enables Robust Iga and Cellular Response Induction in the Lungs of Mice and Improves Protection against Pulmonary Mycobacterial Challenge. Front. Cell. Infect. Microbiol. 2017, 7, 445. [CrossRef]

110. Ai, W.; Yue, Y.; Xiong, S.; Xu, W. Enhanced Protection against Pulmonary Mycobacterial Challenge by Chitosan-Formulated Polyepitope Gene Vaccine Is Associated with Increased Pulmonary Secretory Iga and Gamma-Interferon(+) T Cell Responses. Microbiol. Immunol. 2013, 57, 224-235. [CrossRef]

111. Shim, S.; Park, H.E.; Soh, S.H.; Im, Y.B.; Yoo, H.S. Induction of Th2 Response through Tlr2-Mediated Myd88-Dependent Pathway in Human Microfold Cells Stimulated with Chitosan Nanoparticles Loaded with Brucella abortus Mdh. Microb Pathog. 2020, 142, 104040. [CrossRef] [PubMed]

112. Soh, S.H.; Shim, S.; Im, Y.B.; Park, H.T.; Cho, C.S.; Yoo, H.S. Induction of Th2-Related Immune Responses and Production of Systemic Iga in Mice Intranasally Immunized with Brucella Abortus Malate Dehydrogenase Loaded Chitosan Nanoparticles. Vaccine 2019, 37, 1554-1564. [CrossRef] [PubMed]

113. Lebre, F.; Borchard, G.; Faneca, H.; de Lima, M.C.P.; Borges, O. Intranasal Administration of Novel Chitosan Nanoparticle/DNA Complexes Induces Antibody Response to Hepatitis B Surface Antigen in Mice. Mol. Pharm. 2016, 13, 472-482. [CrossRef] [PubMed]

114. Alkie, T.N.; Yitbarek, A.; Taha-Abdelaziz, K.; Astill, J.; Sharif, S. Characterization of Immunogenicity of Avian Influenza Antigens Encapsulated in Plga Nanoparticles Following Mucosal and Subcutaneous Delivery in Chickens. PLoS ONE 2018, 13, e0206324. [CrossRef] [PubMed]

115. Dehghan, S.; Tafaghodi, M.; Bolourieh, T.; Mazaheri, V.; Torabi, A.; Abnous, K.; Kheiri, M.T. Rabbit Nasal Immunization against Influenza by Dry-Powder Form of Chitosan Nanospheres Encapsulated with Influenza Whole Virus and Adjuvants. Int. J. Pharm. 2014, 475, 1-8. [CrossRef] [PubMed]

116. Liu, Q.; Zheng, X.; Zhang, C.; Shao, X.; Zhang, X.; Zhang, Q.; Jiang, X. Conjugating Influenza a (H1n1) Antigen to N-Trimethylaminoethylmethacrylate Chitosan Nanoparticles Improves the Immunogenicity of the Antigen after Nasal Administration. J. Med. Virol. 2015, 87, 1807-1815. [CrossRef] [PubMed]

117. Abkar, M.; Fasihi-Ramandi, M.; Kooshki, H.; Lotfi, A.S. Oral Immunization of Mice with Omp31-Loaded N-Trimethyl Chitosan Nanoparticles Induces High Protection against Brucella Melitensis Infection. Int. J. Nanomed. 2017, 12, 8769-8778. [CrossRef] 
118. Bento, D.; Staats, H.F.; Gonçalves, T.; Borges, O. Development of a Novel Adjuvanted Nasal Vaccine: C48/80 Associated with Chitosan Nanoparticles as a Path to Enhance Mucosal Immunity. Eur. J. Pharm. Biopharm. 2015, 93, 149-164. [CrossRef]

119. Fullagar, B.; Rao, W.; Gilor, C.; Xu, F.; He, X.; Adin, C.A. Nano-Encapsulation of Bilirubin in Pluronic F127-Chitosan Improves Uptake in Beta Cells and Increases Islet Viability and Function after Hypoxic Stress. Cell Transplant. 2017, 26, 1703-1715. [CrossRef]

120. Shim, S.; Soh, S.H.; Im, Y.B.; Park, H.E.; Cho, C.S.; Kim, S.; Yoo, H.S. Elicitation of Th1/Th2 Related Responses in Mice by Chitosan Nanoparticles Loaded with Brucella Abortus Malate Dehydrogenase, Outer Membrane Proteins 10 and 19. Int. J. Med. Microbiol. 2020, 310, 151362. [CrossRef]

121. Xu, J.; Dai, W.; Wang, Z.; Chen, B.; Li, Z.; Fan, X. Intranasal Vaccination with Chitosan-DNA Nanoparticles Expressing Pneumococcal Surface Antigen a Protects Mice against Nasopharyngeal Colonization by Streptococcus Pneumoniae. Clin. Vaccine Immunol. 2011, 18, 75-81. [CrossRef] [PubMed]

122. Marasini, N.; Ghaffar, K.A.; Giddam, A.K.; Batzloff, M.R.; Good, M.F.; Skwarczynski, M.; Toth, I. Highly Immunogenic Trimethyl Chitosan-Based Delivery System for Intranasal Lipopeptide Vaccines against Group a Streptococcus. Curr. Drug Deliv. 2017, 14, 701-708. [CrossRef] [PubMed]

123. Agency Response Letter GRAS Notice No. GRN 000397. Nutrition Center for Food Safety Applied (2019). GRAS Notice Inventory-Agency Response Letter GRAS Notice No. GRN 000443. Available online: https://wayback.archive-it.org/7993/20171031005742/https://www.fda.gov/Food/ IngredientsPackagingLabeling/GRAS/NoticeInventory/ucm347791.htm (accessed on 20 November 2020).

124. Shariatinia, Z.; Fazli, M. Mechanical Properties and Antibacterial Activities of Novel Nanobiocomposite Films of Chitosan and Starch. Food Hydrocolloids 2015, 46, 112-124. [CrossRef]

125. Aranaz, I.; Acosta, N.; Civera, C.; Elorza, B.; Mingo, J.; Castro, C.; Gandía, M.L.L.; Caballero, A.H. Cosmetics and Cosmeceutical Applications of Chitin, Chitosan and Their Derivatives. Polymers 2018, 10, 213. [CrossRef]

126. Raza, Z.A.; Anwar, F. Fabrication of Chitosan Nanoparticles and Multi-Response Optimization in Their Application on Cotton Fabric by Using a Taguchi Approach. Nano-Struct. Nano-Obj. 2017, 10, 80-90. [CrossRef]

127. Anirudhan, T.S.; Nair, A.S.; Parvathy, J. Extended Wear Therapeutic Contact Lens Fabricated from Timolol Imprinted Carboxymethyl Chitosan-G-Hydroxy Ethyl Methacrylate-G-Poly Acrylamide as a Onetime Medication for Glaucoma. Eur. J. Pharm. Biopharm. 2016, 109, 61-71. [CrossRef]

128. Ishihara, M.; Nakanishi, K.; Ono, K.; Sato, M.; Kikuchi, M.; Saito, Y.; Yura, H.; Matsui, T.; Hattori, H.; Uenoyama, M.; et al. Photocrosslinkable Chitosan as a Dressing for Wound Occlusion and Accelerator in Healing Process. Biomaterials 2002, 23, 833-840. [CrossRef]

129. Sano, H.; Shibasaki, K.; Matsukubo, T.; Takaesu, Y. Effect of Chitosan Rinsing on Reduction of Dental Plaque Formation. Bull. Tokyo Dent. Coll. 2003, 44, 9-16. [CrossRef]

130. Nawrotek, K.; Tylman, M.; Rudnicka, K.; Balcerzak, J.; Kamiński, K. Chitosan-Based Hydrogel Implants Enriched with Calcium Ions Intended for Peripheral Nervous Tissue Regeneration. Carbohydr. Polym. 2016, 136, 764-771. [CrossRef]

131. Lee, Y.M.; Park, Y.J.; Lee, S.J.; Ku, Y.; Han, S.B.; Klokkevold, P.R.; Chung, C.P. The Bone Regenerative Effect of Platelet-Derived Growth Factor-Bb Delivered with a Chitosan/Tricalcium Phosphate Sponge Carrier. J. Periodontol. 2000, 71, 418-424. [CrossRef]

132. Dai, T.; Tanaka, M.; Huang, Y.Y.; Hamblin, M.R. Chitosan Preparations for Wounds and Burns: Antimicrobial and Wound-Healing Effects. Expert Rev. Anti Infect. Ther. 2011, 9, 857-879. [CrossRef]

133. Garg, U.; Chauhan, S.; Nagaich, U.; Jain, N. Current Advances in Chitosan Nanoparticles Based Drug Delivery and Targeting. Adv. Pharm. Bull. 2019, 9, 195-204. [CrossRef]

Publisher's Note: MDPI stays neutral with regard to jurisdictional claims in published maps and institutional affiliations. 